\title{
CORPORATE SOCIAL RESPONSIBILITY DISCLOSURE PADA PERUSAHAAN TERDAFTAR DI INDEKS SRI-KEHATI
}

\author{
STELLA \\ EMIR KHARISMAR \\ DEBBY IRWAN PUTRI \\ Trisakti School of Management, Jl. Kyai Tapa No. 20, Grogol, Jakarta, Indonesia \\ stella@stietrisakti.ac.id
}

\begin{abstract}
The research objective was to analyze the effect of profitability, leverage, company age, company size, and board size on corporate social responsibility disclosure in companies listed on the SRI-KEHATI index. Population data from this study are companies registered in the SRI-KEHATI index. Using a purposive sampling method, it was found that 12 companies were consistently listed in the SRI-KEHATI index for the 2010-2018 period. This study uses multiple linear regression analysis and the panel data approach is tested through Eviews 10 with a fixed effect model to test the hypothesis. The results of this study indicate that profitability, leverage, and board size do not affect corporate social responsibility disclosure, while company age and company size have an effect on corporate social responsibility disclosure.
\end{abstract}

Keywords: Corporate social responsibility disclosure, profitability, leverage, company age, company size, board size

Abstrak: Tujuan penelitian adalah untuk menganalisis pengaruh profitabilitas, leverage, umur perusahaan, ukuran perusahaan, dan ukuran dewan komisaris terhadap corporate social responsibility disclosure pada perusahaan yang terdaftar dalm indeks SRI-KEHATI. Data populasi dari penelitian ini adalah perusahaan yan terdaftar dalam indeks SRI-KEHATI. Menggunakan metode purposive sampling, didapatkan 12 perusahaan yang konsisten terdaftar dalam indeks SRI-KEHATI periode 2010-2018. Penelitian ini menggunakan analisis regresi linear berganda dan pendekatan data panel diuji melalui Eviews 10 dengan model fixed effect untuk menguji hipotesis. Hasil penelitian ini menunjukkan profitabilitas, leverage, dan ukuran dewan komisaris tidak berpengaruh terhadap corporate social responsibility disclosure, sedangkan umur perusahaan dan ukuran perusahaan berpengaruh terhadap corporate social responsibility disclosure.

Kata kunci: Corporate social responsibility disclosure, profitabilitas, leverage, umur perusahaan, ukuran perusahaan, ukuran dewan komisaris

\section{PENDAHULUAN}

Pada dasarnya, perusahaan dipercayakan dengan tanggung jawab tunggal untuk menghasilkan keuntungan dan meningkatkan nilai pemegang saham. Seperti yang diungkapkan oleh Friedman di tahun 1970 yang dikenal dengan profit-maximizing view dimana perusahaan harus beroperasi dengan dasar profit-orientation. Tetapi seiring dengan perubahan jaman, tumbuh kesadaran bersama akan keterbatasan sumber daya alam, kesenjangan sosial yang semakin meningkat, dan kehadiran dunia bisnis yang meluas dalam 
masyarakat. Perusahaan mulai menganut konsep sustainability. Dalam Daft $(2016,166)$, "Sustainability refers to economic development that generates wealth and meets the needs of the current generation while preserving the environment and society so that future generations can meet their needs as well." Dengan konsep sustainability, perusahaan mengukur kesuksesan mereka dengan triple bottom line, yaitu people, planet, dan profit. CSR telah menjadi bagian dari praktik bisnis sejak dulu. Namun, konsep ini mempunyai daya tarik sendiri seiring dengan semakin canggihnya teknologi dan bertambahnya pengetahuan masyarakat.

Kewajiban perusahaan mengenai CSR adalah tanggung jawab yang dapat mengubah persepsi masyarakat dan perusahaan tentang bisnis yang dijalankan sehingga tidak dilihat hanya sebagai tuntutan moral akan tetapi juga kewajiban yang harus dipenuhi oleh perusahaan. Dalam praktik dan literatur, CSR juga disebut sebagai corporate citizenship yang berarti perusahaan harus bertindak sebagai penduduk yang bertanggung jawab dalam masyarakat atas dampak dari aktivitas mereka terhadap tenaga kerja, pemasok, pelanggan, pemegang saham, komunitas, dan lingkungan (Khandelwal dan Bakshi, 2014). Corporate social responsibility di Indonesia diatur oleh pemerintah yang menetapkan dalam ketentuan pasal 74 ayat (1) UUPT Nomor 40 Tahun 2007 mewajibkan perusahaan yang bergerak dibidang sumber daya alam melaksanakan tanggung jawab sosial lingkungan. Selain itu pada ketentuan pasal 15 huruf $b$ UndangUndang Nomor 25 Tahun 2007 tentang Penanaman Modal mewajibkan setiap penanam modal melaksanakan tanggung jawab sosial perusahaan. Berdasarkan dari ketetapan diatas dapat disimpulkan tanggung jawab sosial dan lingkungan harus dilakukan oleh perusahaan yang mengivestasikan modalnya di Indonesia untuk menjaga keharmonisan lingkungan, budaya, dan norma yang diterapkan oleh masyarakat setempat.

Praktik pengungkapan tanggung jawab sosial telah dilakukan oleh perusahaan di Indonesia. Pada laporan tahunannya, perusahaan memasukkan aspek pertangungjawaban sosialnya walaupun dalam bentuk yang relatif sederhana. Perusahaan berhak memilih bentuk pengungkapan yang sesuai dengan kebutuhan dan kompleksitas organisasinya. Pengungkapan CSR berguna selain untuk laporan kegiatan perusahaan dalam menjaga kesejahteraan masyarakat dan lingkungan juga untuk memastikan setiap perusahaan melaksanakan dan berkomitmen dalam menjalankannya.

Dalam penelitian ini, CSRD diukur dengan indicator dalam standar pengungkapan umum Global Reporting Initiatives (GRI) sebagai dasar yang telah disesuaikan oleh Pasal 6 Peraturan Otoritas Jasa Keuangan Nomor 29/PJOK.04/2016 tentang Laporan Tahunan Emiten atau Perusahaan Publik. GRI merupakan pedoman internasional dalam penyusunan sustainability reports yang menginisiasi pelaporan aktivitas sosial dan lingkungan organisasi yang mengacu pada triple bottom line atau 3P (planet, people, profit). Pedoman GRI dikembangkan untuk membantu perusahaan dalam melaporkan kinerja ekonomi, sosial, dan lingkungannya serta untuk meningkatkan akuntabilitas. Pedoman GRI menyediakan standar pengungkapan yang dibagi menjadi dua, yaitu standar pengungkapan umum dan standar pengungkapan spesifik.

Penelitian ini merupakan replikasi dari penelitian sebelumnya (Wulandari, 2018) berjudul "Pengaruh Ukuran Perusahaan, Umur Perusahaan, Ukuran Dewan Komisaris, Profitabilitas, dan Leverage terhadap Pengungkapan Tanggung Jawab Sosial Perusahaan (Studi Empiris pada Perusahaan BUMN yang terdaftar di Bursa Efek Indonesia pada Tahu 2013-2015)" yang menyimpulkan ukuran perusahaan, umur perusahaan, ukuran 
dewan komisaris, profitabilitas, dan leverage berpengaruh terhadap corporate social responsibility disclosure. Dalam penelitian ini, objek yang digunakan adalah perusahaan yang terdaftar di indeks SRI-KEHATI pada periode 2010-2018. Alasan pemilihan objek adalah indeks SRI-KEHATI (Sustainable Responsible Investment-KEHATI) merupakan indeks yang menggunakan prinip keberlanjutan, keuangan, dan tata kelola baik, serta kepedulian terhadap lingkungan hidup sebagai tolak ukurnya. Indeks ini diluncurkan pada 8 Juni 2009 atas hasil kerja sama Bursa Efek Indonesia dengan Yayasan Keanekaragaman Hayati Indonesia (KEHATI) yang bergerak dibidang pelesatarian dan pemanfaatan hayati.

Ada 25 emiten dalam indeks SRIKEHATI yang diseleksi setiap dua periode dalam setahun, yaitu pada bulan April dan Oktober. Mekanisme pemilihan emiten indeks SRI-KEHATI dilaksanakan melalui tiga tahap seleksi, yaitu seleksi negatif, aspek finansial, dan aspek fundamental. Indeks SRI-KEHATI membantu investor dalam menentukan perusahaan publik mana yang memiliki kinerja baik dalam menjalankan usahanya dari sisi tata kelola ekonomi, lingkungan, dan sosial yang dapat disimpulkan dari proses seleksinya. Dan kinerja SRI-KEHATI terbukti seiring dengan berkembangnya "green stock" dengan memiliki return tertinggi diantara indeks saham lainnya ditahun 2016-2017. Dapat disimpulkan bahwa objek penelitian yang digunakan sesuai dengan topik penelitian yaitu corporate social responsibility disclosure. Variabel independen yang digunakan dalam penelitian ini adalah profitabilitas, leverage, umur perusahaan, ukuran perusahaan, dan ukuran dewan komisaris. Peneliti menemukan gap pada data dan penelitian terdahulu mengenai pengaruh variabel independen terhadap variabel dependen yaitu CSRD.

Profitabilitas menggambarkan kemampuan perusahaan mendapatkan laba melalui semua kemampuan dan sumber dana yang ada serta membuat manajemen bebas untuk mengungkapkan CSR kepada pemegang saham (Wulandari, 2018). Hal ini berarti semakin tinggi profitabilitas sebuah perusahaan maka semakin besar pengungkapan informasi sosialnya. Namun ditemukan gap pada variabel profitabilitas yang diukur dengan $R O A$. Pada tahun 2015 PT Astra Internasional Tbk. menurun dari 0.09 menjadi 0.06 namun CSRD-nya meningkat. Pada penelitian terdahulu juga ditemukan gap, Wulandari (2018), Indrayenti dan Jenny (2018) menyimpulkan profitabilitas berpengaruh positif terhadap corporate social responsibility disclosure. Sedangkan Rofiqkoh dan Priyadi (2016) dan Situmorang (2015) menyimpulkan profitabilitas tidak berpengaruh. Leverage digunakan sebagai alat untuk mengukur seberapa besar perusahaan bergantung kepada kreditur dalam membiayai aset perusahaan (Wulandari, 2018). Menurut Octarina dan Muslih (2018) perusahaan yang memiliki leverage tinggi dinilai memiliki risiko keuangan yang tinggi, oleh karena itu perusahaan cenderung akan mengungkapkan tanggung jawab sosial perusahaan. Pada tahun 2016 DAR PT Indofoof Tbk. menurun dari 0.53 menjadi 0.47 sedangkan CSRD-nya meningkat. Penelitian Wulandari (2018) dan Samsiyah (2014) menyimpulkan leverage berpengaruh positif terhadap corporate social responsibility disclosure. Sedangkan Robiah dan Erawati (2017), Pratiwi dan Ismawati (2017) menyimpulkan sebaliknya.

Umur perusahaan adalah lamanya perusahaan berdiri (Arjanggie dan Zulaikha, 2015). Semakin lama perusahaan berdiri semakin banyak informasi yang diungkapkan seiring dengan bertambahnya pengetahuan dan tuntuan masyarakat. Namun CSRD PT Unilever Indonedia Tbk. menurun ditahun 2016 meskipun umurnya bertambah. Pada penelitian yang dilakukan Wulandari (2018), Dewi (2018), Ratnasari dan Meita (2017) menyimpulkan umur perusahaan berpengaruh positif terhadap corporate social responsibility disclosure. Sebaliknya, penelitian Arjanggie dan Zulaikha (2015) menyimpulkan umur perusahaan tidak 
berpengaruh terhadap corporate social responsibility disclosure. Ukuran perusahaan merupakan identifikasi besar atau kecilnya suatu perusahaan yang dapat dinilia dari total aktiva, total penjualan, kapitalisasi pasar, jumlah tenaga kerja, dan sebagainya (Indrayenti dan Jenny, 2018). Menurut Octarina dan Muslih (2018), besarnya ukuran perusahaan akan mempengaruhi pengungkapan CSR karena perusahaan yang memiliki sumber daya aktiva yang besar maka aktivitas yang dilakukan lebih banyak dan berdampak pada masyarakat dan lingkungan sosial, sehingga perlu mengungkapkan tanggung jawab sosial perusahaan. Dari tahun 2016 ukuran perusahaan PT Bank Danamon Indonesia Tbk. terus meningkat namun CSRD-nya konstan 104. Menurut hasil penelitian Wulandari (2018), Indrayenti dan Jenny (2018) ukuran perusahaan berpengaruh terhadap corporate social responsibility disclosure. Sedangkan menurut Budiman (2015) ukuran perusahaan tidak berpengaruh. Ukuran dewan komisaris menggambarkan jumlah dewan komisaris yang menjabat dalam perusahaan. Semakin banyak dewan komisaris dalam perusahaan semakin banyak juga tanggung jawab sosial yang diungkapkan karena perhatian yang ditujukan semakin besar. PT Bank Central Asia Tbk. mempunyai ukuran dewan komisaris yang konstan dari tahun 2011 yaitu 5 dan CSRD-nya meningkat. Menurut Wulandari (2018) ukuran dewan komisaris berpengaruh, sedangkan Herawati (2015) menyimpulkan sebaliknya.

Dari beberapa research gap mengenai faktorfaktor yang berpengaruh terhadap corporate social responsibility disclosure, peneliti bermaksud melaksanakan penelitian untuk memperkuat penelitian Wulandari (2018). Dan menguji apakah hasil penelitian tersebut akan bersifat konsisten terhadap perusahaanperusahaan dalam indeks SRI-KEHATI serta melanjutkan dan menyempurnakan penelitianpenelitian terdahulu.

\section{Teori Keagenan}

Teori ini pertama kali dikemukakan oleh Jensen dan Meckilng ditahun 1976. Dikatakan dalam perusahaan terjadi agency relationship yaitu terdapat suatu hubungan yang bersifat kontraktual antara pihak pemilik atau pemegang saham (principal) dengan pihak manajemen (agent). Agency relationship tersebut yang memunculkan teori bahwa agent mempunyai kewajiban untuk memberikan kinerja sesuai yang diinginkan oleh principal. Menurut Gitman dan Zutter (2015, 67), "Principal-agent relationship is an arrangement in which agent acts on the behalf of a principal." Pada kenyataannya pihak agent dan principal tersebut memiliki kepentingan masing-masing sehingga muncul permasalahan (conflict of interest). Dalam Gitman dan Zutter $(2015,68)$, "Agency problems that arise when managers place personal goals ahead of the goals of shareholders." Ini akan menimbulkan agency costs untuk penyelesaian perbedaan pendapat antara agent dan principal. Menurut Salighi et al. (2017) dengan adanya pengungkapan, agent memberikan informasi lebih yang menunjukkan bahwa mereka telah mengambil langkah sesuai kepentingan principal. Dan sebagai tambahan pengungkapan juga digunakan sebagai informasi terhadap masyarakat. Maka pengungkapan informasi seperti tanggung jawab sosial yang mencakup ekonomi, lingkungan dan sosial berperan dalam pengurangan agency costs. Pemerintah juga memberikan pedoman pengungkapan untuk memastikan perusahaan beroperasi secara transparan bagi principal dan masyarakat.

\section{Teori Legitimasi}

Teori legitimasi berassal dari konsep legitimasi organisasi yang telah didefinisikan oleh Dowling dan Pfeffer ditahun 1975. Dikatakan bahwa legitimasi organisasi adalah sebuah kondisi dimana nilai perusahaan berdampingan dengan nilai masyarakat dimana perusahaan beroperasi. Teori ini kemudian 
dikembangkan menjadi teori legitimasi. Menurut Salehi dan Rezanezhad (2017), "The legitimacy theory is based on the idea of a social contract between an organization and society, and the organization try to report the CSR so that they are approved by the community because organizations can continue their life until they are considered legitimate by the community." Perusahaan akan berusaha untuk mendapatkan citra baik di mata masyarakat dan sebagai timbal balik diberikan sumber daya.

Menurut Rofikoh dah Priyadi (2016) perusahaan mengungkapkan informasi yang berhubungan dengan organisasi sosial, komunitas masyarakat, dan lingkungan yang diperlukan. Informasi tersebut dapat diungkapkan dalam sustainability report sebagai akuntabilitas terhadap publik untuk mendapat legitimasi masyarakat dan menjelaskan dampak sosial dan lingkungan yang ditimbulkan oleh perusahaan. Dapat disimpulkan bahwa perusahaan membutuhkan validasi dari masyarakat untuk mendapatkan sumber daya manusia dan alam yang ditawarkan oleh masyarakat setempat. Pengungkapan CSR membantu dalam memberikan transparasi bagaimana perusahaan beroperasi dan pengaruhnya terhadap masyarakat dan lingkungan.

\section{Corporate Social Responsibility Disclosure}

Pengertian tanggung jawab sosial ditetapkan pasal 1 ayat (3) Undang-Undang Nomor 40 tahun 2009 tentang Perseroan Terbatas (UUPT), menyebutkan, "Tanggung jawab sosial dan lingkungan adalah komitmen Perseroan untuk berperan serta dalam pembangungan ekonomi berkelanjutan guna meningkatkan kualitas kehidupan dan lingkungan yang bermanfaat, baik bagi Perseroan sendiri, komunitas setempat, maupun masyarakat pada umumnya." Dalam Daft (2017, 155), "Corporate social responsibility (CSR) is management's obligation to make choices and take actions that will contribute to the welfare and interest of the society, not just the organization."

Menurut Pratiwi dan Ismawati (2017), "Corporate social responsibility merupakan bentuk kerjasama antara perusahaan dengan segala sesuatu atau segala hal yang secara langsung maupun tidak langsung berinteraksi dengan perusahaan tersebut untuk menjamin keberadaan dan kelangsungan usaha (sustainability) suatu perusahaan." Berdasarkan pengertian diatas CSRD adalah pengungkapan oleh perusahaan untuk melaporkan kinerja perusahaan yang ,ancakup tanggung jawab sosial secara ekonomi, lingkungan, dan sosial.

\section{Profitabilitas}

Menurut Gitman dan Zutter $(2015,655)$, "Profitability is the relationship between revenues and costs generated by using the firm's assets - both current and fixed - in productive activities." Menurut Wulandari (2018), "Profitabilitas merupakan kemampuan perusahaan dalam menghasilkan laba sehingga mampu meningkatkan nilai pemegang saham perusahaan." Menurut Rofiqkoh dan Priyadi (2016), "Profitabilitas merupakan indikator kinerja yang dilakukan manajemen dalam mengelola kekayaan perusahaan yang ditunjukkan oleh laba yang dihasilkan." Berdasarkan pengertian diatas dapat disimpulkan bahwa profitabilitas adalah keefektifan perusahaan dalam menggunakan aset untuk mendapatkan laba. Dan dalam penelitian ini profitabilitas diukur dengan return on assets.

$\mathrm{H}_{1}$ : Profitabilitas berpengaruh terhadap corporate social responsibility disclosure

\section{Leverage}

Menurut Gitman dan Zutter $(2015,560)$, "The effects that fixed cost have on the returns that shareholders earn; higher leverage generally results in higher but move volatile returns" Menurut Octarina dan Muslih (2018), "Leverage mencerminkan risiko keuangan perusahaan karena dapat menggambarkan 
struktur modal perusahaan dan mengetahui risiko tak tertagihnya suatu utang." Menurut Wulandari (2018), "Leverage merupakan keadaan yang terjadi pada saat perusahaan memiliki biaya tetap yang harus ditanggung." Berdasarkan definisi diatas dapat disimpulkan bahwa leverage adalah seberapa besar aset perusahaan yang didanai oleh hutang. Dan dalam penelitian ini leverage diukur dengan debt to asset ratio.

$\mathrm{H}_{2}$ : Leverage berpengaruh terhadap corporate social responsibility disclosure

\section{Umur Perusahaan}

Menurut Wulandari (2018), "Umur perusahaan yaitu lamanya suatu perusahaan berdiri yang dihitung sejak berdirinya tahun perusahaan tersebut." Menurut Ratnasari dan Meita (2017), "Umur perusahaan menunjukkan sudah berapa lama perusahaan mampu bertahan dari awal mulai perusahaan sampai sekarang." Menurut Arjanggie dan Zulaikha (2015), "Umur perusahaan menggambarkan lamanya perusahaan tersebut berdiri dan melangsungkan kegiatan usahanya." Berdasarkan definisi diatas dapat disimpulkan bahwa umur perusahaan terhitung sejak awal perusahaan berdiri.

$\mathrm{H}_{3}$ : Umur perusahaan berpengaruh terhadap corporate social responsibility disclosure

\section{Ukuran Perusahaan}

Menurut Wulandari (2018), "Ukuran perusahaan merupakan suatu skala yang berfungsi untuk mengklasifikasikan besar kecilnya entitas bisnis." Menurut Wahyuningsih (2018), "Ukuran perusahaan merupakan ukuran besar kecilnya suatu perusahaan." Menurut Indrayenti dan Jenny (2018), "Ukuran perusahaan merupakan identifikasi besar atau kecilnya suatu perusahaan yang dapat dinilai dari total nilai aktiva, total penjualan, jumlah tenaga kerja dan sebagainya." Berdasarkan definisi diatas dapat disimpulkan bahwa ukuran perusahaan dapat diukur dengan jumlah aset, penjualan, dan profit yang dimiliki perusahaan. Dalam penelitian ini ukuran perusahaan diukur dengan In(total asset)

$\mathrm{H}_{4}$ : Ukuran Perusahaan berpengaruh terhadap corporate social responsibility disclosure

\section{Ukuran Dewan Komisaris}

Menurut Gitman dan Zutter $(2015,54)$ "Board of directors is a group elected by the firm's stockholders and typically responsible for approving strategic goals and plans, setting general policy, guiding corporate affairs, and approving major expenditures." Menurut Simamora (2016) dewan komisaris adalah wakil shareholder dalam entitas bisnis berbadan hukum Perseroan Terbatas (PT) yang berfungsi mengawasi pengelolaan perusahaan yang dilaksanakan oleh manajemen (direksi), dan bertanggung jawab untuk menentukan apakah manajemen memenuhi tanggung jawab mereka dalam mengembangkan dan menyelenggarakan pengendalian internal perusahaan. Menurut Putra (2016), "Dewan komisaris merupakan salah satu elemen penting bagi tata kelola perusahaan yang bertugas mengawasi pelaksanaan aktivitas perusahaan sehingga dikelola dengan semestinya oleh agen mereka." Berdasarkan pengertian diatas dapat disimpulkan bahwa ukuran dewan komisaris adalah jumlah orang yang mempunyai posisi mengawasi perusahaan dalam perusahaan.

$\mathrm{H}_{5}$ : Ukuran Dewan Komisaris berpengaruh terhadap corporate social responsibility disclosure 


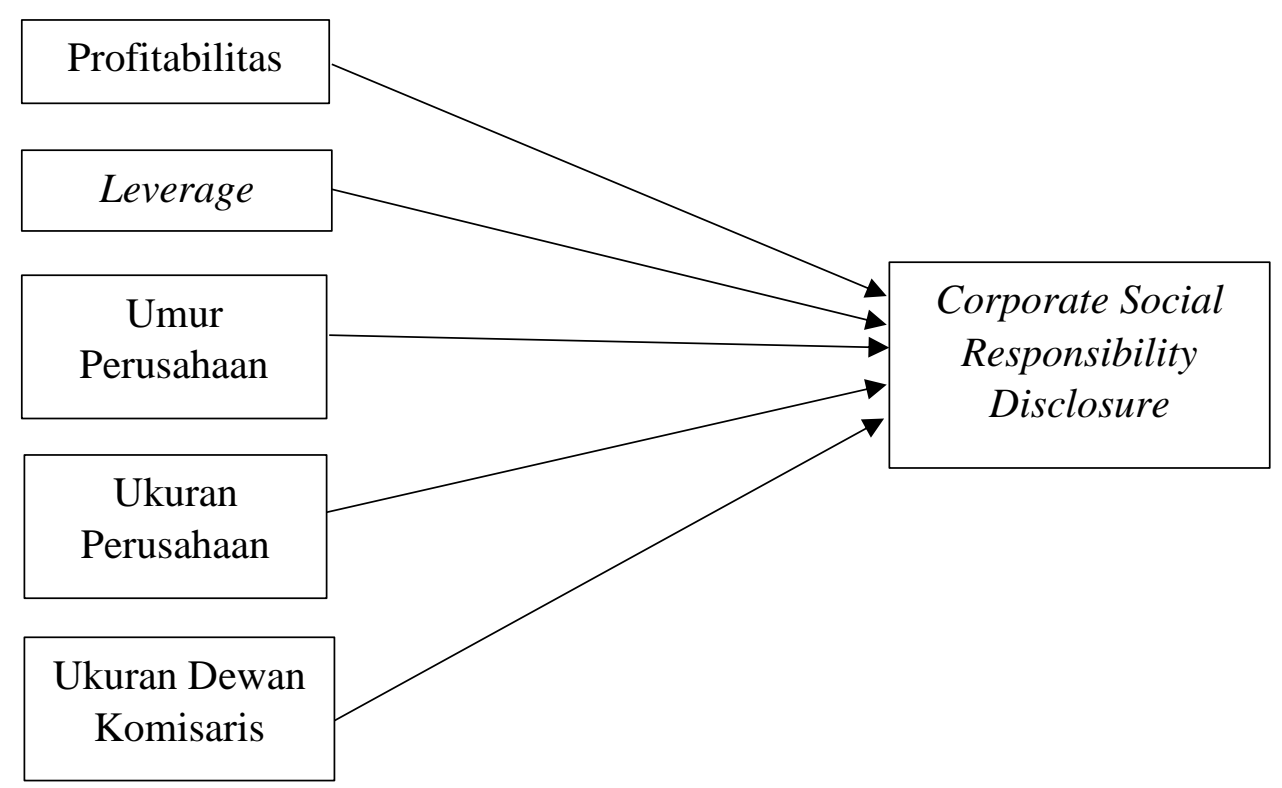

\section{Gambar 1 Model Penelitian}

\section{METODA PENELITIAN}

Dalam penelitian ini objek yang digunakan adalah perusahaan yang terdaftar di Indeks SRI-KEHATI periode 2010-2018. Teknik pengambilan sampel akan dilakukan dengan menggunakan teknik non probability sampling. Menurut Sugiyono $(2014,120)$ "Non probability sampling adalah teknik pengambilan sampel dengan tidak memberi peluang/kesempatan sama bagi setiap unsur anggota populasi untuk dipilih menjadi sampel." Dengan ini, peneliti menggunakan teknik purposive sampling, dimana menurut Sugiyono $(2014,122)$ "Sampling Purposive adalah teknik penentuan sampel dengan pertimbangan tertentu." Kriteria yang digunakan adalah perusahaan yang terdaftar secara konsisten di Indeks SRIKEHATI selama periode 2010-2018 dan mempublikasikan laporan keuangan per 31 Desember serta laporan tahunan.
Masing-masing item pada setiap indikator pengungkapan dalam checklist diberi skor 1. Maka jika perusahaan mengungkapkan semua item kategori pengungkapan tanggung jawab sosial skor maksimal yang akan diperoleh adalah 108.

Profitabilitas

Return on Assets $=\frac{\text { Laba bersih setelah pajak }}{\text { Total aset }}$ Leverage

Debt to total asset ratio $=\frac{\text { Total utang }}{\text { Total aset }}$ Umur Perusahaan Lamanya suatu perusahaan berdiri yang dihitung sejak berdirinya tahun perusahaan tersebut.

Ukuran Perusahaan

SIZE $=\ln ($ total asset $)$

Ukuran Dewan Komisaris

$\mathrm{UDK}=\sum$ dewan komisaris 


\section{HASIL PENELITIAN}

Tabel 1 Statistik Deskriptif

\begin{tabular}{lllll}
\hline Variabel & Rata-rata & Maksimum & Minimum & $\begin{array}{l}\text { Deviasi } \\
\text { Standar }\end{array}$ \\
\hline CSRD & 90.33333 & 104 & 65 & 9.255461 \\
ROA & 0.110958 & 0.467 & 0.01 & 0.107639 \\
DAR & 0.528301 & 0.8934 & 0.1571 & 0.213458 \\
AGE & 58.77778 & 162 & 18 & 34.38766 \\
SIZE & 19.46398 & 30.53 & 11.52 & 5.393726 \\
UDK & 6.564815 & 13 & 3 & 1.890820 \\
\hline
\end{tabular}

Nilai probabilitas 0.0000 lebih kecil dari pada a (0.05). Nilai chi-square statistic 242.275080 lebih besar dari pada nilai tabel chisquare dengan a $(0.05)$ dan degree of freedom $(d f)=5(242.275080>11.07050)$. Hal ini berarti model yang baik digunakan adalah model fixed effect

Nilai dari Jarque-Bera 3.653411, sementara nilai chi-squares dengan a $(0.05)$ dan $\mathrm{df}=2$ adalah 5.991. Hal ini membuktikan nilai Jarque-Bera lebih kecil dari nilai chi-squares, dan nilai probability adalah 0.160943 lebih besar dari pada a (0.05), dapat disimpulkan $\mathrm{H}_{0}$ tidak dapat ditolak, sehingga data berdistribusi normal. Selain itu skewness dan kurtosis memenuhi kriteria normalitas yaitu, skewness mendekati 0 , dan kurtosis yang nilainya mendekati 3. Dengan demikian dapat disimpulkan data berdistribusi normal.

Profitabilitas memiliki korelasi dengan leverage sebesar -0.178016 , artinya tidak terjadi multikolinearitas antara profitabilitas dengan leverage. Profitabilitas memiliki korelasi dengan umur perusahaan sebesar 0.212251 , artinya tidak terjadi multikolinearitas antara profitabilitas dengan umur perusahaan. Profitabilitas memiliki korelasi dengan ukuran perusahaan sebesar 0.063231 , artinya tidak terjadi multikolinearitas antara profitabilitas dengan ukuran perusahaan. Profitabilitas memiliki korelasi dengan ukuran dewan komisaris sebesar -0.233913 , artinya tidak terjadi multikolinearitas antara profitabilitas dengan ukuran dewan komisaris
Leverage memiliki korelasi dengan profitabilitas 0.178016 , artinya tidak terjadi multikolinearitas antara leverage dengan profitabilitas. Leverage memiliki korelasi dengan umur perusahaan 0.093382 , artinya tidak terjadi multikolinearitas antara leverage dengan umur perusahaan. Leverage memiliki korelasi dengan ukuran perusahaan -0.252540 , artinya tidak terjadi multikolinearitas antara leverage dengan ukuran perusahaan. Leverage memiliki korelasi dengan ukuran dewan komisaris -0.233913 , artinya tidak terjadi multikolinearitas antara leverage dengan ukuran dewan komisaris. Umur perusahaan memiliki korelasi dengan profitabilitas 0.212251 , artinya tidak terjadi multikolinearitas antara umur perusahaan dengan profitabilitas. Umur perusahaan memiliki korelasi dengan leverage 0.093382 , artinya tidak terjadi multikolinearitas antara umur perusahaan dengan leverage. Umur perusahaan memiliki korelasi dengan ukuran perusahaan -0.499141, artinya tidak terjadi multikolinearitas antara umur perusahaan dengan ukuran perusahaan. Umur perusahaan memiliki korelasi dengan ukuran dewan komisaris 0.017903 , artinya tidak terjadi multikolinearitas antara umur perusahaan dengan ukuran dewan komisaris. Ukuran perusahaan memiliki korelasi dengan profitabilitas -0.063231 , artinya tidak terjadi multikolinearitas antara ukuran perusahaan dengan profitabilitas. Ukuran perusahaan memiliki korelasi dengan leverage -0.252540 , artinya tidak terjadi multikolinearitas antara 
ukuran perusahaan dengan leverage. Ukuran perusahaan memiliki korelasi dengan umur perusahaan -0.499141 , artinya tidak terjadi multikolinearitas antara ukuran perusahaan dengan umur perusahaan. Ukuran perusahaan memiliki korelasi dengan ukuran dewan komisaris -0.418680 , artinya tidak terjadi multikolinearitas antara ukuran perusahaan dengan ukuran dewan komisaris. Ukuran dewan komisaris memiliki korelasi dengan profitabilitas -0.233913 , artinya tidak terjadi multikolinearitas antara ukuran dewan komisaris dengan profitabilitas. Ukuran dewan komisaris memiliki korelasi dengan leverage 0.020991, artinya tidak terjadi multikolinearitas antara ukuran dewan komisaris dengan leverage. Ukuran dewan komisaris memiliki korelasi dengan umur perusahaan 0.017903 , artinya tidak terjadi multikolinearitas antara ukuran dewan komisaris dengan umur perusahaan. Ukuran dewan komisaris memiliki korelasi dengan ukuran perusahaan -0.418680 , artinya tidak terjadi multikolinearitas antara ukuran dewan komisaris dengan ukuran perusahaan perusahaan.

Dapat diketahui bahwa profitabilitas memiliki nilai probabilitas sebesar 0.3730 , leverage memiliki nilai probabilitas sebesar 0.9876, umur perusahaan memiliki nilai probabilitas sebesar 0.7974 , ukuran perusahaan memiliki nilai probabilitas sebesar 0.8970 , ukuran dewan komisaris memiliki nilai probabilitas sebesar 0.5743 , dapat diketahui secara keseluruhan nilai probabilitas lebih besar dari pada a (0.05), dapat diartikan bahwa data bersifat homoskedastisitas.

\section{Tabel 2 Uji Goodness of Fit}

\begin{tabular}{lr}
\hline F-statistic & 28.60263 \\
Prob(F-Statistic) & 0.00000 \\
\hline
\end{tabular}

Berdasarkan tabel 2, dapat disimpulkan nilai F-statistik lebih besar dari nilai F-tabel dengan $a=0.05$ yaitu $2.31(28.60263>2.31)$. Hasil ini didukung oleh nilai probabilitas Fstatistik sebesar 0.00000 yang lebih kecil dari alpha $0.05(0.00000<0.05)$, sehingga model dapat dikatakan fit. Nilai koefisien korelasi $(R)$ adalah 0.834136 , hubungan antara profitabilitas, leverage, umur perusahaan, ukuran perusahaan, dan ukuran dewan komisaris secara bersama-sama dengan corporate social responsibility disclosure adalah sangat kuat karena berada diantara 0,80-1,00. Besarnya koefisien determinasi $\left(R^{2}\right)$ sebesar 0.804973 yang artinya variasi variabel dependen yaitu corporate social responsibility disclosure yang dapat dijelaskan oleh variasi variabel independen yaitu profitabilitas, leverage umur perusahaan, ukuran perusahaan, dan ukuran dewan komisaris adalah sebesar $80.49 \%$ sisanya $19.51 \%$ dijelaskan oleh variasi variabel lain yang tidak termasuk kedalam penelitian ini.

Tabel 3 Analisis Regresi Berganda

\begin{tabular}{lllll}
\hline Variable & Coefficient & Std. Error & t-Statistic & Prob \\
\hline C & 39.37805 & 15.24176 & 2.583564 & 0.0114 \\
ROA & 7.837452 & 18.28318 & 0.428670 & 0.6692 \\
DAR & -1.072709 & 8.555951 & -0.125376 & 0.9005 \\
AGE & 4.030073 & 0.266449 & 15.12510 & 0.0000 \\
SIZE & -9.674479 & 0.936569 & -10.32970 & 0.0000 \\
UDK & 0.316460 & 0.600007 & 0.527428 & 0.5992 \\
\hline
\end{tabular}

Nilai $t$-statistic sebesar 0.428670 yang mana berada di daerah hipotesis nol tidak dapat ditolak yaitu $\mathrm{t} \geq-\mathrm{t}_{\mathrm{a} / 2}(0.428670 \geq-1.987)$ sehingga dapat disimpulkan bahwa $\mathrm{H}_{a}$ ditolak. 
Kesimpulan ini didukung oleh nilai probabilitas dari profitabilitas sebesar 0.6692 lebih besar dari $\alpha(0.6692>0.05)$. Hal ini berarti $\mathrm{H}_{a}$ ditolak, sehingga didapat kesimpulan bahwa tidak terdapat pengaruh profitabilitas terhadap corporate social responsibility disclosure pada perusahaan yang terdaftar dalam indeks SRIKEHATI periode 2010-2018.

Nilai $t$-statistic sebesar -0.125376 yang mana berada di daerah Ha ditolak yaitu $\mathrm{t} \geq-\mathrm{t}_{\mathrm{a} / 2}$ $(-0.125376 \geq-1.987)$. Kesimpulan ini didukung oleh nilai probabilitas dari leverage sebesar 0.9005 lebih besar dari $\alpha(0.9005>0.05)$. Hal ini berarti tidak terdapat pengaruh leverage terhadap corporate social responsibility disclosure pada perusahaan yang terdaftar dalam indeks SRI-KEHATI periode 2010-2018.

Nilai $t$-statistic sebesar 15.12510 yang mana berada di daerah Ha diterima, yaitu $\mathrm{t} \geq \mathrm{t}_{\mathrm{a} / 2}$ $(15.12510 \geq 1.987)$ sehingga dapat disimpulkan bahwa $\mathrm{H}_{a}$ diterima. Kesimpulan ini didukung oleh nilai probabilitas dari umur perusahaan sebesar 0.0000 lebih kecil dari $\alpha(0.0000<0.05)$. $\mathrm{Hal}$ ini berarti $\mathrm{H}_{a}$ diterima, sehingga didapat kesimpulan bahwa terdapat pengaruh umur perusahaan terhadap corporate social responsibility disclosure pada perusahaan yang terdaftar dalam indeks SRI-KEHATI periode 2010-2018.

Nilai $t$-statistic sebesar -10.32970 yang mana berada di daerah Ha diterima, yaitu $\mathrm{t} \leq$ $t_{a / 2}$ atau $(-10.32970 \leq-1.987)$ sehingga dapat disimpulkan bahwa $\mathrm{H}_{a}$ diterima. Kesimpulan ini didukung oleh nilai probabilitas dari ukuran perusahaan sebesar 0.0000 lebih kecil dari $\alpha$ $(0.0000>0.05)$. Hal ini berarti $\mathrm{H}_{a}$ diterima, sehingga didapat kesimpulan bahwa terdapat pengaruh ukuran perusahaan terhadap corporate social responsibility disclosure pada perusahaan yang terdaftar dalam indeks SRIKEHATI periode 2010-2018.
Nilai $t$-statistic sebesar 0.527428 yang mana berada di daerah Ha ditolak yaitu atau $\mathrm{t} \leq$ $t_{a / 2}(0.527428 \leq 1.987)$ sehingga dapat disimpulkan bahwa $\mathrm{H}_{a}$ ditolak. Kesimpulan ini didukung oleh nilai probabilitas dari ukuran dewan komisaris sebesar 0.5992 lebih besar dari $\alpha(0.5992>0.05)$. Hal ini berarti $\mathrm{H}_{\mathrm{a}}$ ditolak, sehingga didapat kesimpulan bahwa tidak terdapat pengaruh ukuran dewan komisaris terhadap corporate social responsibility disclosure pada perusahaan yang terdaftar dalam indeks SRI-KEHATI periode 2010-2018.

\section{PENUTUP}

Simpulan yang didapat dari hasil penelitian ini adalah pofitabilitas tidak berpengaruh terhadap corporate social responsibility disclosure. Hasil penelitian ini konsisten dengan penelitian yang dilakukan oleh Rofiqkoh dan Priyadi (2016) dan Situmorang (2015). Leverage tidak berpengaruh terhadap corporate social responsibility disclosure. Hasil penelitian ini konsisten dengan penelitian yang dilakukan oleh Robiah dan Erawati (2017), Pratiwi dan Ismawati (2017). Umur perusahaan berpengaruh terhadap corporate social responsibility disclosure. Hasil penelitian ini konsisten dengan penelitian yang dilakukan oleh Wulandari (2018), Dewi (2018), Ratnasari dan Meita (2017). Ukuran perusahaan berpengaruh terhadap corporate social responsibility disclosure. Hasil penelitian ini konsisten dengan penelitian yang dilakukan oleh Wulandari (2018) dan Indrayenti dan Jenny (2018). Ukuran dewan komisaris tidak berpengaruh terhadap corporate social responsibility disclosure, Hasil penelitian ini konsisten dengan penelitian yang dilakukan oleh Herawati (2015). 


\section{REFERENCES:}

Arjanggie, Aulia Rizki \& Zulaikha. 2015. Pengaruh Profitabilitas dan Umur Perusahaan terhadap Pengungkapan Tanggung Jawab Sosial Perusahaan Studi Empiris Pada Perusahaan Industri Dasar dan Kimia yang Terdaftar di Bursa Efek Indonesia. Diponegoro Journal of Accounting. 4(3).

Budiman, Nita Andriyani. 2015. Faktor-Faktor yang Mempengaruhi Pengungkapan Tanggung Jawab Sosial Perusahaan. Jurnal Riset Akuntansi Mercu Buana. 1(1).

Daft, Richard L. 2016. Management, Twelfth Edition. USA: Cengage Learning.

Dewi, Ratih Utami. 2018. Pengaruh Ukuran Perusahaan, Ukuran Dewan Komisaris, dan Umur Perusahaan terhadap Corporate Social Responsibility Disclosure. Jurnal Kajian Akuntansi. 20(1).

Dewi, Sofia Prima \& Keni. 2013. Pengaruh Umur Perusahaan, Profitabilitas, Ukuran Perusahaan, dan Leverage terhadap Pengungkapan Tanggung Jawab Sosial Perusahaan. Jurnal Bisnis dan Akuntansi, 15(1).

Gitman, Lawrence J. \& Chad J. Zutter. 2015. Principles of Managerial Finance, Fourteenth Edition. United States of America: Pearson Education.

Gujarati, Damodar N. \& Dawn C. Potter. 2012. Dasar-Dasar Ekonometrika, Edisi 5, Buku 2. Jakarta: Salemba Empat.

Herawati, Heti. 2015. Corporate Governance, Karakteristik Perusahaan, dan Pengungkapan Corporate Social Responsibility. Jurnal Riset Akuntansi dan Perpajakan. 2(2), 203-217.

Indrayenti \& Jenny. 2018. Analisis Pengaruh Ukuran Perusahaan, Ukuran Dewan Komisaris, Profitabilitas dan Leverage terhadap Pengungkapan Tanggung Jawab Sosial Pada Sektor Industri Barang Konsumsi Yang Terdaftar Di Bursa Efek Indonesia Periode 2014-2016. Jurnal Akuntansi dan Keuangan, 9(2), 1-13.

Khandelwala, Ruchi dan Swarna Bakshib. 2014. The New CSR Regulation in India: The Way Forward. Procedia: Economics and Finance. 11, $60-67$

Megginson, William L. 1997. Corporate Finance Theory. Massaschussets: Addison Wesley.

Octarina, Nisha \& Majidah Muhammad Muslih. 2018. Pengungkapan Corporate Social Responsibility: Ukuran Dan Pertumbuhan Perusahaan, Serta Risiko Keuangan. Jurnal Riset Akuntansi Kontemporer. 10(1), 34-41.

Ratnasari, Niki \& Iren Meita. 2017. Pengaruh Karakteristik Perusahaan terhadap Pengungkapan Tanggung Jawab Sosial Perusahaan. Jurnal Riset Manajemen dan Bisnis. 2(S1), 201-214.

Robiah, Almari M. dan Teguh Erawati. 2017. Pengaruh Leverage, Size, dan Kepemilikan Manajemen terhadap Corporate Social Responsibility Disclosure. Jurnal Akuntansi Dewantara. 1(1).

Rofigkoh, Esti dan Maswar Patuh Priyadi. 2016. Pengaruh Profitabilitas, Leverage Dan Ukuran Perusahaan Terhadap Pengungkapan Tanggung Jawab Sosial Perusahaan. Jurnal IImu dan Riset Akuntansi. 5(10).

Samsiyah, Eka dan Kurnia. 2014. Pengaruh Profitabilitas, Likuiditas, dan Leverage Terhadap Pengungkapan Tanggung Jawab Sosial Perusahaan. Jurnal \& Riset Akuntansi. 3(4).

Sugiyono. 2014. Metode Penelitian Bisnis. Edisi Keenam. Bandung: Alfabeta.

Undang No. 25 Tahun 2007 tentang Penanaman Modal

Widarjono, Agus. 2013. Ekonometrika: Pengantar dan Aplikasinya. Edisi Keempat. Yogyakarta: UPP STIM YKPN.

Winarno, Wing Wahyu. 2015. Analisis Ekonometrika dan Statistika dengan Eviews. Edisi Keempat. Yogyakarta: UPP STIM YKPN.

Wulandari, Windy. 2018. Pengaruh Ukuran Perusahaan, Umur Perusahaan, Ukuran Dewan Komisaris, Profitabilitas dan Leverage terhadap Pengungkapan Tanggung Jawab Sosial Perusahaan: Studi Empiris pada Perusahaan BUMN yang Terdaftar di Bursa Efek Indonesia pada Tahun 2013-2015. Jurnal Online Mahasiswa Fakultas Ekonomi, 1(1).

Yayasan SRI-KEHATI. 2016. Indeks SRI-KEHATI. Kehati.or.id, (http://kehati .or.id/indeks-sri-kehati/). 
